\title{
IMPLEMENTASI PENDIDIKAN KARAKTER PADA PEMBELAJARAN IPS DI MADRASAH TSANAWIYAH
}

\section{Ardilla Elfira Safitri}

Victor Novianto

Jurusan Pendidikan IPS, Program Pascasarjana, UPY

email: iraftr9@gmail.com, victor@upy.ac.id

\begin{abstract}
Abstrak
Penelitian ini bertujuan untuk mengetahui nilai-nilai karakter, hasil implementasi pendidikan karakter, dan faktor pendorong dan penghambat implementasi pendidikan karakter pada pembelajaran IPS. Penelitian ini menggunakan metode kualitatif. Teknik pengumpulan data menggunakan observasi, wawancara, dan dokumentasi. Teknik analisis data menggunakan analisis data kualitatif model Miles dan Huberman. Hasil penelitian menunjukkan bahwa bentuk implementasi pendidikan karakter pada pembelajaran IPS adalah siswa membantu teman, guru memberikan tugas, siswa membaca asmaul khusna, siswa hadir ke kelas tepat waktu, guru dan siswa melakukan tanya jawab. Hasil implementasi pendidikan karakter adalah siswa senang membantu teman, siswa dapat mengerjakan tugas mandiri, siswa rajin beribadah, siswa tidak terlambat datang ke kelas, dan siswa dapat menjawab pertanyaan. Faktor pendorong implementasi pendidikan karakter adalah siswa merupakan seorang santri dan faktor penghambatnya adalah guru belum memahami tentang pendidikan karakter.
\end{abstract}

Kata kunci: pendidikan karakter, pembelajaran IPS, Madrasah Tsanawiyah 
Ardilla Elfira Safitri, Victor Novianto|

\begin{abstract}
This research aims to understand about the character values, the results of the implementation of character education, and the driving and inhibiting factors of implementation of character education in social study learning. This research used qualitative method. The methods of date collection are observation, interview, and documentation. The data was analyzed by Miles and Huberman model's. This research showed that the implementations of character values in social study learning are the students help for their friends who need a help, teachers give a homework, the students read asmaul khusna, the students come to class on time, and the question and answer process between students and teachers. The results of the implementation of character education are the students like to help their friends, the students can work on task individually, the students pray 5 times, the students don't come late to the class, and the students can answer the question. Driving factor of the implementation of character education in social study learning in MTs An-Nawawi 01 Berjan Purworejo are students of MTs AnNawawi 01 Berjan Purworejo are santris from islamic boarding school and this inhibiting factor is teachers do not understand about character education.

Word Key: Character Education, Social Study Learning, Madrasah Tsanawiyah
\end{abstract}

\title{
Pendahuluan
}

Penyimpangan sosial merupakan salah satu masalah sosial di Indonesia. Penyimpangan sosial terjadi di kalangan masyarakat umum dan siswa. Berdasarkan teori fungsi dari Emile Durkeim (dalam Jones, 2009:48), faktor terjadinya penyimpangan sosial, antara lain faktor lingkungan, fisik, dan keturunan. Contoh penyimpangan sosial di kalangan siswa, antara lain menyontek, berbohong, membolos, terlambat sekolah, tawuran antar pelajar, bentrokan, vandalisme, merokok, balapan liar, mabok-mabokan, pengeroyokan, dan sebagainya. Penyimpangan sosial membawa dampak negatif bagi siswa, keluarga, sekolah, maupun masyarakat. Upaya untuk mencegah penyimpangan sosial adalah 
penanaman nilai-nilai karakter sejak usia dini. Penanaman nilainilai karakter dapat dilakukan melalui pembelajaran $11 \mathrm{mu}$ Pengetahuan Sosial (IPS).

Pendidikan karakter ditetapkan oleh Kementrian Pendidikan dan Kebudayaan (Kemendikbud) untuk dilaksanakan di sekolah. Sekolah memiliki peran penting terhadap pembentukan karakter siswa. Ditemukan guru hanya berperan sebagai pengajar tanpa menerapkan pendidikan karakter di dalamnya. Faktor peran dominan guru tersebut adalah kurangnya pemahaman guru terhadap program pendidikan karakter. Guru diharapkan tidak hanya berperan sebagai pengajar, melainkan juga berperan sebagai pendidik.

MTs An-Nawawi 01 Berjan Purworejo merupakan sekolah berbasis Pondok Pesantren di Kabupaten Purworejo yang menjalankan program pendidikan karakter. Pendidikan karakter di MTs An-Nawawi 01 Berjan Purworejo juga telah dilakukan dalam pembelajaran IPS. Berdasarkan visi sekolah,tujuan pendidikan karakter di MTs An-Nawawi 01 Berjan Purworejo adalah mewujudkan siswa menjadi generasi penerus bangsa yang bertaqwa, berprestasi, dan santun. Adanya pendidikan karakter, siswa diharapkan dapat terhindar dari penyimpangan sosial. Siswa juga diharapkan dapat menjadi manusia yang beriman dan bertaqwa. Beberapa sifat yang wajib dimiliki dan ditanamkan oleh siswa MTs An-Nawawi 01 Berjan Purworejo tersebut, antara lain sifat sikap sopan santun, peduli sosial, keimanan, peduli lingkungan, kemandirian, kedisiplinan, cinta tanah air, nasionalisme, cinta damai, dan sebagainya.

Faktor terbentuknya karakter siswa MTs An-Nawawi 01 Berjan Purworejo adalah penanaman nilai-nilai karakter oleh seluruh guru MTs An-Nawawi 01 Berjan Purworejo kepada siswa 
Ardilla Elfira Safitri, Victor Novianto|

yang dilakukan secara terus menerus. Berdasarkan observasi di lapangan, penanaman nilai-nilai karakter di MTs An-Nawawi 01 Berjan Purworejo dilakukan mulai dari sebelum sampai setelah proses kegiatan belajar mengajar berlangsung. Pendidikan karakter wajib dilaksanakan di MTs An-Nawawi 01 Berjan Purworejo. Pendidikan karakter juga telah diterapkan dalam kegiatan belajar mengajar. Berdasarkan visi misi sekolah yang kemudian diangkat menjadi peraturan sekolah MTs An-Nawawi 01 Berjan Purworejo, guru mata pelajaran wajib menjalankan pendidikan karakter dalam kegiatan belajar mengajar. Guru MTs An-Nawawi 01 Berjan Purworejo dibiasakan untuk berperan sebagai pengajar dan pendidik bagi siswa.

\section{Hakekat Karakter}

Sebelum membahas tentang apa itu pendidikan karakter, perlu membahas dan mengenal terlebih dahulu tentang karakter. Aeni (2014:22) menjelaskan tentang pengertian karakter adalah:

"Istilah karakter diambil dari bahasa Yunani "Charassian" yang berarti "to mark" atau menandai dan memfokuskan bagaimana mengaplikasikan nilai kebaikan dalam bentuik tindakan atau tingkah laku, sehingga orang yang tidak jujur, kejam, rakus, dan perilaku jelek lainnya dapat dikatakan sebagai berkarakter jelek. Sebaliknya, orang yang perilakunya sesuai dengan kaidah moral disebut dengan berkarakter mulia”.

Sunarti (2005:1) mengungkapkan bahwa karakter merupakan istilah yang menunjuk kepada aplikasi nilai-nilai kebaikan dalam bentuk tingkah laku. Walaupun istilah karakter dapat menunjuk kepada karakter baik atau karakter buruk, namun dalam aplikasinya orang dikatakan berkarakter jika mengaplikasikan nilai-nilai kebaikan dalam perilakunya. 
Secara psikologis, pendidikan karakter dari Lickona (2012:84) harus mencangkup beberapa dimensi penalaran. Dimensi penalaran dalam pendidikan karakter harus berlandaskan pada 3 komponen karakter yang baik (components of good character) yang saling berhubungan. Komponen-komponen karakter menurut Lickona (2012:84) dapat digambarkan sebagai berikut:

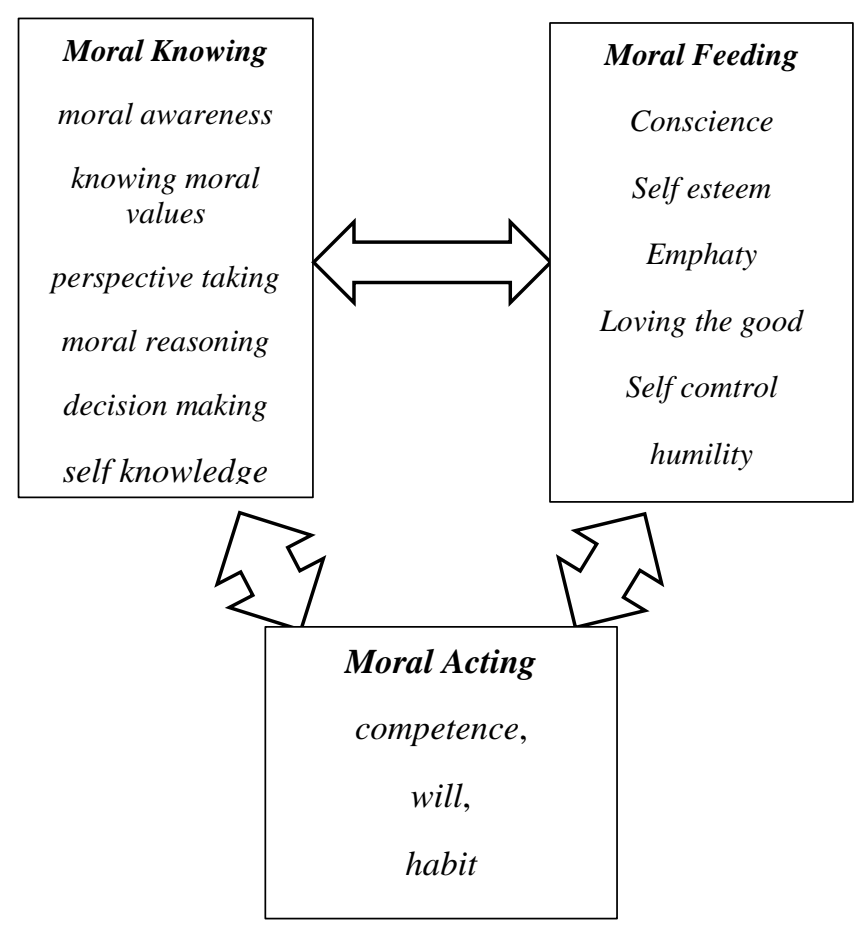

Gambar 1. Bagan Komponen-Komponen Karakter

Pendidikan karakter merupakan program pemerintah yang telah ditetapkan oleh Kementrian Pendidikan dan Kebudayaan (Kemendikbud) untuk dilaksanakan di dunia pendidikan. Pendidikan karakter berperan penting terhadap pembentukan karakter siswa yang digunakan untuk menciptakan siswa menjadi Warga Negara Indonesia yang memiliki sifat dan karakter yang baik. Pengertian pendidikan karakter oleh Berkowitz dan Bier (2005:2) adalah sebagai berikut:

"Character education is a national movement creating schools that foster ethical, responsible, and caring young people by 
Ardilla Elfira Safitri, Victor Novianto

modeling and teaching good character through emphasis on universal values that we all share".

Berdasarkan definisi di atas, maka dapat disimpulkan bahwa pendidikan karakter merupakan suatu gerakan nasional dalam menciptakan sekolah untuk mengembangkan siswa dalam memiliki etika, tanggung jawab, dan kepedulian dengan menerapkan dan mengajarkan karakter-karakter yang baik melalui penekanan pada nilai-nilai universal.

Mumpuni (2018:16) mengungkapkan bahwa pendidikan karakter adalah proses yang dilakukan untuk mengembangkan pola pikir siswa dalam mengadopsi nilai-nilai karakter. Nilai-nilai karakter sebagai hasil dari pendidikan karakter sebagai hasil dari pendidikan karakter diharapkan akan mengantarkan terbentuknya manusia seutuhnya yang dapat mengisi kemerdekaan.

Demi memudahkan pelaksanaan pendidikan karakter, Zuchdi (2011:29) mengungkapkan bahwa terdapat konsep pendidikan 9 pilar yang berasal dari nilai-nilai luhur universal (lintas agama, budaya, dan sulu). Diharapkan melalui internalisasi 9 pilar karakter tersebut, siswa menjadi manusia yang memiliki karakter cinta damai, tanggung jawab, jujur, santun, percaya diri, dan karakter mulia lainnya. Adapun kesembilan pilar nilai-nilai karater yang baik dan universal tersebut, antara lain:

1) Karakter cinta Tuhan dan segenap ciptaan-Nya;

2) Kemandirian dan tanggung jawab;

3) Kejujuran/amanah, diplomatis;

4) Hormat dan santun;

5) Dermawan, suka tolong menolong, dan gotong royong/ kerjasama;

6) Percaya diri dan pekerja keras; 
7) Kepemimpinan dan keadilan;

8) Baik dan rendah hati; dan

9) Karakter toleransi, kedamaian, dan kesatuan.

Pendidikan karakter harus tetap berakar pada agama, adat istiadat, nilai-nilai sosial budaya dalam upaya membentuk siswa menjadi warga negara yang baik. Supardi (2011:189) mengungkapkan bahwa banyak jenis nilai-nilai karakter yang perlu dikembangkan dan menjadi bagian dari hidup siswa. Adapun nilai-nilai karakter yang perlu dikembangkan dan menjadi bagian hidup bagi siswa, antara lain nilai keimanan dan ketakwaan, keadilan dan kesetaraan, nasionalisme, patriotisme dan jati diri bangsa, demokrasi dan tanggung jawab, di samping care values seperti kejujuran, keadilan, kedisiplinan, kebersamaan, kepedulian, dan kemandirian.

Tujuan pendidikan karakter berdasarkan pendapat dari Wahyuni, dkk (2012:4) adalah mengembangkan potensi siswa sebagai manusia dan Warga Negara yang memiliki nilai karakter, mengembangkan nilai-nilai karakter manusia sesuai dengan nilainilai yang berlaku, mananamkan jiwa kepemimpinan dan tanggung jawab dalam rangka mempersiapkan generasi penerus bangsa, menjadikan siswa yang mandiri, kreatif, berwawasan kebangsaan, dan mengembangkan lingkungan sekolah sebagai lingkungan belajar yang aman, jujur, kreatif, serta bersahabat.

\section{Hakekat Pembelajaran IPS}

Salah satu mata pelajaran wajib yang ditemukan oleh siswa dari jenjang sekolah dasar sampai sekolah menengah yaitu mata pelajaran Ilmu Pengetahuan Sosial (IPS). Peran pembelajaran IPS tidak lepas dengan adanya pendidikan karakter. Pendidikan karakter menjadi begian penting atas terselenggarakannya 
Ardilla Elfira Safitri, Victor Novianto

pembelajaran IPS. Pembelajaran IPS memiliki arti relevan dengan pendidikan karakter. Pembelajaran IPS dan pendidikan karakter juga memiliki tujuan yang sama yaitu membentuk karakter baik kepada siswa.

Supardi (2011:182) mengungkapkan bahwa pendidikan IPS di SMP dilakukan dengan pendekatan terpadu. Pendidikan IPS di SMP/MTs juga menekankan pada keterampilan siswa dalam memecahkan masalah mulai dari ruang lingkup diri sampai pada masalah yang kompleks. Masalah manusia selalu akan berkaitan dengan berbagai aspek yang tidak hanya lingkup ilmu sosial tetapi juga di luar ilmu sosial.

Trianto (2015: 175) mengungkapkan bahwa beberapa karakteristik dari mata pelajaran IPS di SMP/MTs, antara lain:

1) Ilmu Pengetahuan Sosial merupakan gabungan dari unsurunsur geografi, sejarah, ekonomi, hukum dan politik, kewarganegaraan, sosiologi, bahkan juga bidang humaniora, pendidikan, dan agama

2) Standar Kompetensi dan Kompetensi Dasar IPS berasal dari struktur keilmuan geografi, sejarah, ekonomi, dan sosiologi, yang dikemas sedemikian rupa sehingga menjadi pokok bahasan atau topik (tema) tertentu

3) Standar Kompetensi dan Kompetensi Dasar IPS juga menyangkut berbagai masalah sosial yang dirumuskan dengan pendekatan interdisipliner dan multidisipliner

4) Standar Kompetensi dan Kompetensi Dasar dapat menyangkut peristiwa dan perubahan kehidupan masyarakat dengan prisnsip sebab akibat, kewilayahan, adaptasi dan pengelolaan lingkungan, struktur, proses dan masalah sosial serta upayaupaya perjuangan hidup agar survive seperti pemenuhan kebutuham, kekuasaan, keadilan dan jaminan kemanan. 
Tujuan mata pelajaran IPS di tingkat SMP/MTs sederajat berdasarkan pendapat dari Supardan (2011:66) yaitu: 1) Mengenal konsep-konsep yang berkaitan dengan kehidupan masyarakat dan lingkungannya; 2) Memiliki kemampuan dasar untuk berpikir logis dan kritis, rasa ingin tahu, inquiri, memecahkan masalah, dan keterampilan dalam kehidupan sosial; 3) Memiliki komitmen dan kesadaran terhadap nilai-nilai sosial dan kemanusiaan; dan 4) Memiliki kemampuan berkomunikasi, bekerjasama, dan berkompetisi dalam masyarakat yang majemuk, di tingkat lokal, nasional, dan global.

\section{Metode Penelitian}

Metode penelitian ini adalah metode penelitian kualitatif yang bertujuan untuk mengetahui implementasi pendidikan karakter pada pembelajaran IPS. Desain penelitian yang digunakan dalam penelitian ini adalah survey, yang digunakan untuk menjelaskan tentang nilai-nilai karakter pada pembelajaran IPS, hasil implementasi pendidikan karakter pada pembelajaran IPS, dan faktor pendorong maupun penghambat implementasi pendidikan karakter pada pembelajaran IPS.

Penelitian dilaksanakan di MTs An-Nawawi 01 Berjan, tepatnya berada di Kabupaten Purworejo, Provinsi Jawa tengah. Waktu penelitian dilaksanakan pada bulan Juli sampai September 2018 dengan subjek sasaran penelitian adalah guru IPS dan siswa putri maupun putra tingkat SMP/MTs sederajat.

Data primer dikumpulkan dengan menggunakan observasi dan wawancara sedangkan data sekunder menggunakan dokumentasi. Alat pengumpulan data ini menggunakan lembar observasi, lembar wawanacara, dan dokumentasi. Alat pengumpulan data digunakan untuk mengetahui bentuk nilai- 
Ardilla Elfira Safitri, Victor Novianto

nilai karakter pada pembelajaran IPS, hasil implementasi pendidikan karakter pada pembelajaran IPS, dan faktor pendukung maupun penghambat implementasi pendidikan karakter pada pembelajaran IPS.

Data dianalisis dengan menggunakan analisis data model Miles dan Huberman yang terdiri dari 3 aktivitas, seperti 1) Reduksi data, yaitu merangkum dan menggolongkan pokok-pokok data penelitian yang dianggap penting dan layak untuk dimasukkan ke dalam kesimpulan data hasil penelitian. 2) Penyajian data, yaitu menyusun rumusan kesimpulan sementara yang diperoleh berdasarkan hasil reduksi data yang dilakukan sebelumnya. 3) Menarik kesimpulan yang dikemukakan pada tahap awal dan didukung oleh adanya bukti-bukti yang dinilai valid dan konsisten berdasarkan hasil pengumpulan data yang diperoleh peneliti ketika kembali ke lapangan.

\section{Hasil Penelitian}

Kurikulum pembelajaran yang digunakan pada pembelajaran IPS di MTs An-Nawawi 01 Berjan Purworejo adalah kurikulum 2013. Guru IPS berperan sebagai pengajar, pengarah, dan pendidik. Guru IPS bertugas untuk menyampaikan materi dan menanamkan nilai-nilai karakter kepada siswa. Tujuan pembelajaran IPS di MTs An-Nawawi 01 Berjan Purworejo adalah melatih siswa untuk berpikir kritis dan menjadi individu yang memiliki keterampilan sosial. Metode pembelajaran yang digunakan pembelajaran IPS di MTs An-Nawawi 01 Berjan Purworejo dinilai bervariasi sedangkan media pembelajaran yang digunakan saat ini belum dapat dikatakan bervariasi dan cenderung bersifat konvensional. Jenis metode pembelajaran IPS yang digunakan di MTs An-Nawawi 01 Berjan Purworejo adalah 
metode ceramah, diskusi, dan tanya jawab sedangkan media pembelajaran IPS yang digunakan adalah media buku guru dan buku siswa. Guru IPS melaksanakan proses pembelajaran sesuai dengan ketetapan Kurikulum dari Madrasah dan Kementerian Agama (Observasi Kelas bulan Juli sampai Agustus 2018).

Guru IPS wajib menerapkan pendidikan karakter dalam pembelajaran IPS di MTs An-Nawawi 01 Berjan Purworejo. Guru IPS menanamkan nilai-nilai karakter kepada siswa sesuai dengan materi yang disampaikan. Pendidikan karakter di MTs An-Nawawi 01 Berjan Purworejo memiliki peran penting terhadap pembentukan karakter dan meningkatkan kompetensi di bidang ilmu pengetahuan.

Implementasi pendidikan karakter pada pembelajaran IPS di MTs An-Nawawi 01 Berjan Purworejo dilakukan mulai dari kegiatan perencanaan, pelaksanaan, dan penilaian. Melalui Rencana Pelaksanaan Pembelajaran (RPP), guru IPS merancang kegiatan pembelajaran dan mengintegrasikan nilai-nilai karakter di dalamnya. Sebelum diterapkan dalam proses kegiatan belajar mengajar, kepala sekolah memeriksa dan menilai kelayakan RPP yang telah disusun. Kepala sekolah juga memastikan bahwa guru IPS telah memasukkan nilai-nilai karakter di dalamnya. Dalam pelaksanaan pembelajarannya, seluruh siswa selalu mengawali proses kegiatan belajar mengajar dengan berdo'a dan membaca asmaul khusna. Sementara dalam penilaian mencangkup penilaian afektif, kognitif, dan psikomotorik yang telah ditentukan dalam sistem penilaian Kurikulum 2013.

Bedasarkan hasil indentifikasi, terdapat 18 nilai karakter yang diterapkan di MTs An-Nawawi 01 Berjan Purworejo. Nilainilai karakter yang diterapkan pada pembelajaran IPS disesuaikan dengan materi yang diajarkan. Beberapa nilai karakter yang 
Ardilla Elfira Safitri, Victor Novianto

dikembangkan melalui pembelajaran IPS di MTs An-Nawawi 01 Berjan Purworejo, antara lain nilai peduli sosial, kemandirian, keimanan, kedisiplinan dan kreatif. Indikator nilai-nilai karakter pada pembelajaran IPS di MTs An-Nawawi 01 Berjan Purworejo secara umum, telah diperoleh berdasarkan hasil observasi kelas putra dan putri yang dilaksanakan pada bulan Juli sampai Agustus 2018, dapat digambarkan sebagai berikut:

Tabel 1. Nilai-Nilai Karakter Pada Pembelajaran IPS

di MTs An-Nawawi 01 Berjan Purworejo

\begin{tabular}{|c|c|c|}
\hline Jo & $\begin{array}{c}\text { Nilai } \\
\text { Karakter }\end{array}$ & tasi \\
\hline 1 & Peduli sosial & 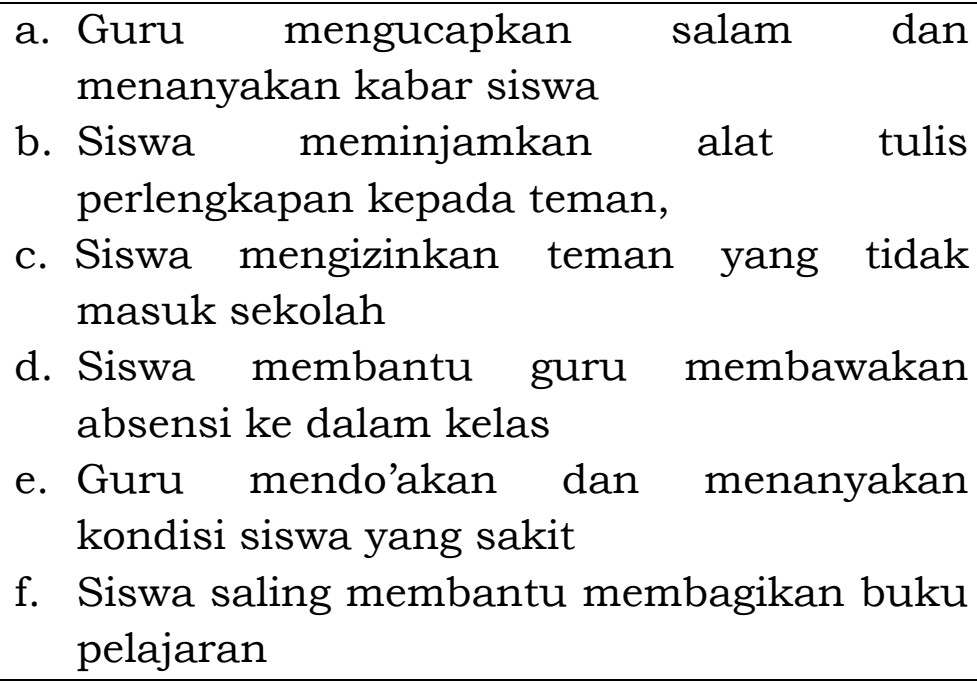 \\
\hline 2 & Kemandirian & $\begin{array}{l}\text { a. Siswa mengerjakan soal-soal tugas } \\
\text { individu secara mandiri } \\
\text { b. Siswa membaca materi secara mandiri } \\
\text { c. Siswa mencatat materi yang dipelajari }\end{array}$ \\
\hline 3 & Keimanan & $\begin{array}{l}\text { a. Siswa membaca doa dan asmaul khusna } \\
\text { sebelum kegiatan belajar mengajar. } \\
\text { b. Siswa menjaga hubungan baik kepada } \\
\text { sesama } \\
\text { c. Siswa harus bersikap baik selama kegiatan } \\
\text { belajar mengajar berlangsung } \\
\text { d. Siswa salam ketikan selesai kegiatan } \\
\text { belajar mengajar }\end{array}$ \\
\hline 4 & a & a. Siswa hadir k \\
\hline
\end{tabular}




\begin{tabular}{cc}
\hline & b. Guru memulai dan mengakhiri proses \\
& kegiatan belajar tepat waktu \\
c. Siswa mengumpulkan tugas tepat waktu \\
d. Guru mengabsen kehadiran siswa dan \\
memastikan tidak ada siswa yang \\
terlambat \\
e. Siswa dipastikan telah berada di dalam \\
kelas sebelum kegiatan belajar mengajar \\
f. Guru mengakhiri kegiatan belajar mengajar \\
sesuai dengan waktu yang ditentukan \\
\hline Kreatif \\
a. Siswa menjawab pertanyaan yang diajukan \\
oleh guru, \\
b. Siswa membuat karya pribadi seperti \\
menggambar peta \\
c. Siswa mempresesntasikan hasil diskusi \\
kelompok di depan kelas \\
d. Siswa mengajukan pertanyaan ketika \\
menemukan materi yang kurang dipahami
\end{tabular}

(Sumber: Data primer yang diolah, 2018)

Indikator bentuk implementasi pendidikan karakter pada pembelajaran IPS di MTs An-Nawawi 01 Berjan Purworejo juga ditentukan berdasarkan hasil wawancara kepada responden. Siswa putri dan putra MTs An-Nawawi 01 Berjan Purworejo juga berpendapat bahwa guru IPS dan siswa putri telah menerapkan nilai-nilai karakter karakter tersebut pada pembelajaran IPS. Bentuk-bentuk implementasi nilai-nilai karakter pada pembelajaran IPS kelas putri di MTs An-Nawawi 01 Berjan Purworejo yang dilakukan oleh guru IPS dan siswa putri, antara lain untuk menunjukkan sikap peduli sosial, siswa bersikap dermawan dan rendah hati kepada sesama teman seperti siswa meminjamkan alat tulis kepada teman yang membutuhkan dan siswa mengajarkan teman yang belum dapat memahami materi yang diajarkan di sekolah. 
Ardilla Elfira Safitri, Victor Novianto

Sikap kemandirian seperti guru memberikan tugas untuk dikerjakan oleh siswa seperti memberikan pekerjaan individu yang harus diselesaikan secara mandiri dan guru memberi kesempatan siswa mempelajari materi secara mandiri sebelum guru menjelaskan materi secara mendalam dan meluas; sikap keimanan seperti guru membiasakan siswa untuk mengucapkan hamdalah dan salam setelah proses kegiatan belajar mengajar dan guru mengajarkan kepada siswa untuk tidak bersikap buruk dan menghormati guru dan sesama teman; sikap kedisiplinan seperti guru memberi sanksi kepada siswa yang terlambat dalam mengikuti proses kegiatan belajar mengajar dan guru selalu hadir ke dalam kelas tepat waktu sesuai dengan jadwal yang ditentukan; sikap kreatif seperti guru memberikan kesempatan kepada siswa untuk menunjukkan kreatif mereka dalam bermain drama dan siswa membuat peta lokasi jarak dari asrama pondok pesantren ke sekolah (Wawancara kepada 24 siswa Pi tanggal 13, 19, dan 20 September 2018).

Sementara bentuk-bentuk implementasi nilai-nilai karakter pada pembelajaran IPS di MTs An-Nawawi 01 Berjan Purworejo pada kelas putra yang dilakukan oleh guru IPS dan siswa putra, antara lain untuk menunjukkan sikap peduli sosial, siswa teman yang sedang mengalami kesulitan dalam menguasai materi maupun mengerjakan soal pertanyaan dan siswa bersikap dermawan dengan meminjamkan bolpoin dan uang bila teman tidak membawa; sikap kemandirian seperti guru memberikan tugas individu untuk dikerjakan dan dikerjakan secara mandiri dan guru meminta siswa untuk meringkas materi secara mandiri; sikap keimanan seperti guru membiasakan siswa untuk mengucapkan hamdalah dan salam setelah proses kegiatan belajar mengajar berlangsung dan guru mengajarkan kepada siswa untuk 
menghormati dan menyayangi antar sesama; sikap kedisiplinan seperti guru mengingatkan dan menasehati siswa agar selalu hadir ke sekolah tepat waktu, tidak membolos, mengumpulkan tugas tepat waktu dan guru selalu tidak membolos untuk mengajar; sikap kreatif seperti guru mengajak siswa untuk bermain peran di dalam kelas dengan materi interaksi sosial dan guru memberikan motivasi kepada siswa agar berani bertanya dan menjawab pertanyaan yang diajukan oleh guru"(Wawancara kepada 16 siswa Pa, 13 dan 17 September 2018).

Implementasi pendidikan karakter pada pembelajaran IPS di MTs An- Nawawi 01 Berjan Purworejo dapat membawa pengaruh yang positif terhadap pembentukan karakter siswa. Siswa MTs AnNawawi 01 Berjan Purworejo dapat menunjukkan sikap peduli sosial, kemandirian, keimanan, kedisiplinan, dan kreatif dalam pembelajaran IPS. Beberapa hasil implementasi pendidikan karakter pada pembelajaran IPS di MTs An-Nawawi 01 Berjan Purworejo secara umum, ditentukan berdasarkan hasil observasi kelas putra dan putri yang dilaksanakan pada bulan Juli sampai Agustus 2018, dapat digambarkan sebagai berikut:

Tabel 2. Hasil Implementasi Pendidikan Karakter Pada

Pembelajaran IPS di MTs An-Nawawi 01 Berjan Purworejo

\begin{tabular}{|c|c|c|}
\hline No & $\begin{array}{c}\text { Nilai } \\
\text { Karakter }\end{array}$ & Hasil Implementasi \\
\hline 1 & Peduli sosial & $\begin{array}{l}\text { a. Siswa senang membantu teman yang } \\
\text { sedang kesusahan } \\
\text { b. Siswa senang menolong teman yang sedang } \\
\text { sakit } \\
\text { c. Siswa saling berbagi kepada sesama teman } \\
\text { d. Siswa senang membantu mengizinkan } \\
\text { teman yang tidak hadir ke sekolah karena } \\
\text { alasan sedang sakit dan memiliki } \\
\text { kepentingan } \\
\text { e. Siswa senang membantu guru }\end{array}$ \\
\hline
\end{tabular}




\begin{tabular}{|c|c|c|}
\hline & & $\begin{array}{l}\text { membawakan absensi ke dalam kelas } \\
\text { f. Siswa saling membantu membagikan buku } \\
\text { sebelum kegiatan belajar mengajar } \\
\text { g. Siswa memiliki sikap toleransi kepada } \\
\text { sesama siswa yang memiliki perbedaan } \\
\text { suku }\end{array}$ \\
\hline 2 & Kemandirian & $\begin{array}{l}\text { a. Siswa telah memiliki motivasi untuk belajar } \\
\text { secara mandiri dan tidak bergantung } \\
\text { kepada orang lain } \\
\text { b. Siswa terbiasa memilih buku di } \\
\text { perpustakaan } \\
\text { c. Siswa terbiasa mengerjakan soal-soal tugas } \\
\text { secara mandiri }\end{array}$ \\
\hline 3 & Keimanan & $\begin{array}{l}\text { a. Siswa rajin membaca doa dan asmaul } \\
\text { khusna sebelum kegiatan belajar mengajar. } \\
\text { b. Siswa rutin menjalankan sholat dhuha di } \\
\text { luar kegiatan belajar mengajar. } \\
\text { c. Siswa rajin menjalankan sholat } 5 \text { waktu } \\
\text { d. Siswa dapat menjaga hubungan baik } \\
\text { kepada sesama siswa maupun guru } \\
\text { e. Siswa dapat bersikap baik selama kegiatan } \\
\text { belajar mengajar berlangsung } \\
\text { f. Siswa terbiasa mengucapkan hamdalah dan } \\
\text { salam selesai kegiatan belajar mengajar } \\
\text { g. Siswa menghormati orang yang lebih tua }\end{array}$ \\
\hline 4 & Kedisiplinan & $\begin{array}{l}\text { a. Siswa selalu berusaha mengerjakan tugas } \\
\text { rumah di rumah } \\
\text { b. Siswa selalu berusaha mengumpulkan } \\
\text { tugas tepat waktu } \\
\text { c. Siswa selalu berusaha hadir ke sekolah } \\
\text { tepat waktu } \\
\text { d. Siswa dapat menyelesaikan tugas secara } \\
\text { maksimal } \\
\text { e. Siswa selalu berusaha mematuhi peraturan } \\
\text { sekolah } \\
\text { f. Siswa selalu mengambil dan } \\
\text { mengembalikan buku sesuai tempatnya dan } \\
\text { jumlahnya }\end{array}$ \\
\hline 5 & Kreatif & mencoba \\
\hline
\end{tabular}




\begin{tabular}{|l|l|}
\hline & \multicolumn{3}{|c|}{ pertanyaan yang diajukan oleh guru } \\
b. Siswa mengalami kesulitan dalam \\
menyusun kata-kata untuk menjawab \\
pertanyaan \\
c. Siswa berusaha menyelesaikan tugas \\
membuat peta yang diberikan oleh guru \\
d. Siswa kurang mampu berpikir kritis untuk \\
menjawab pertanyaan guru \\
e. Siswa dapat mengerjakan tugas kelompok \\
dengan baik hasil \\
f. Siswa berani mempresentasikan hasi di depan kelas \\
diskusi
\end{tabular}

(Sumber: Data primer yang diolah, 2018)

Siswa putri dan putra MTs An-Nawawi 01 Berjan Purworejo juga menunjukkan bahwa implementasi pendidikan karakter telah membawa hasil yang positif terhadap sikap belajar IPS siswa di sekolah. Hasil implementasi pendidikan karakter pada pembelajaran IPS di MTs An-Nawawi 01 Berjan Purworejo lainnya pada kelas putri MTs An-Nawawi 01 Berjan Purworejo, misalnya siswa selalu bersikap rendah hati dan ramah kepada sesama siswa dan orang lain; Siswa dapat mengerjakan tugas individu yang diberikan oleh guru secara mandiri dan tidak bergantung kepada orang lain; Siswa rutin berdoa setiap sebelum dan setelah melaksanakan kegiatan belajar mengajar; Siswa selalu menaati semua peraturan yang disusun dan ditetapkan oleh sekolah; dan siswa berani mempresentasikan hasil diskusi di depan kelas.

Sementara hasil implementasi pendidikan karakter pada pembelajaran IPS di MTs An-Nawawi 01 Berjan Purworejo lainnya pada kelas putra MTs An-Nawawi 01 Berjan Purworejo, misalnya ketika di dalam kelas, siswa selalu menghormati dan menghargai setiap perbedaan yang dimiliki oleh sesama siswa; Siswa dapat mempelajari materi yang akan diajarkan secara mandiri; Siswa selalu mengucapkan hamdalah dan salam setelah proses 
Ardilla Elfira Safitri, Victor Novianto

pembalajaran IPS berakhir; Siswa selalu hadir ke dalam kelas tepat waktu, tidak meninggalkan jam pelajaran, dan mengumpulkan tugas-tugas rumah tepat waktu; dan siswa mampu menunjukkan keberanian mereka dalam mempresentasikan hasil diskusi kelompok di depan kelas.

Dalam rangka meningkatkan keefektivitas program pendidikan karakter, implementasi pendidikan karakter di MTs An-Nawawi 01 Berjan Purworejo juga dilakukan berdasarkan hasil pengembangan kultur sekolah. Pendidikan karakter berbasis kultur sekolah yang dimaksud adalah pendidikan karakter yang dilakukan melalui berbagai macam tradisi yang dibentuk oleh madrasah dan kegiatan ekstrakurikuler. Sekolah MTs An-Nawawi 01 Berjan Purworejo mengembangkan program pendidikan karakter melalui kegiatan yang berasal dari tradisi madrasah dan melalui kegiatan ekstrakurikuler. Kegiatan-kegiatan tersebut rutin dilaksanakan di luar jam sekolah. Tradisi dan kegiatan ekstrakurikuler sekolah tersebut diikuti oleh seluruh siswa putri dan putra MTs An-Nawawi 01 Berjan Purworejo maupun guru MTs An-Nawawi 01 Berjan Purworejo.

Bentuk tradisi dan kegiatan ekstrakurikuler yang telah diadakan dan dilaksanakan oleh MTs An-Nawawi 01 Berjan Purworejo untuk menanamkan nilai-nilai karakter kepada siswa, antara lain:

1) Upacara bendera rutin setiap hari senin pagi untuk menanamkan karakter cinta tanah air,

2) Paskibra rutin sebelum memperingati hari besar nasional untuk menanamkan karakter kedisiplinan dan nasionalisme,

3) Kepramukaan rutin setiap hari sabtu untuk menanamkan karakter kedisiplinan. 
4) Pemilihan ketua osis rutin pada waktu satu tahun sekali untuk menanamkan karakter demokratis,

5) Sholat dhuha, membaca doa, dan membaca asmaul khusna rutin sebelum kegiatan belajar mengajar untuk menanamkan karakter keimanan,

6) Infaq rutin setiap hari rabu pagi untuk menanamkan karakter peduli sosial,

7) Apel pagi rutin setiap hari kamis pagi hari untuk menanamkan karakter kedisiplinan,

8) Bersalaman antara seluruh siswa kepada bapak/ibu guru rutin pada setiap pagi hari menjelang siswa masuk sekolah untuk menanamkan karakter peduli sosial dan saling menghargai,

9) Khataman Al-Qur'an rutin pada setiap peringatan hari besar agama islam untuk menanamkan karakter keimanan.

Keberhasilan pelaksanaan program pendidikan karakter di lingkungan MTs An-Nawawi 01 Berjan Purworejo, disebabkan karena adanya berbagai macam dukungan yang berasal dari berbagai pihak. Terdapat tokoh-tokoh yang dari luar maupun dalam yang mendukung terselenggarakannya program pendidikan karakter di MTs An-Nawawi 01 Berjan Purworejo.

"Sekolah ini pernah mendapatkan kunjungan dari kepala desa dan ketua lurah. Ketika mengunjungi sekolah ini, kedua pejabat tersebut ikut berpartisipasi dalam pelaksanaan upacara bendera wajib yang sudah rutin dilaksanakan setiap hari senin. Pada saat itu, kedua pejabat tersebut memberikan nasihat dan motivasi kepada para siswa secara langsung. Beliau menasehati agar siswa dapat bersemangat untuk terus belajar, selalu bersikap baik, dan harus menunjukkan prestasi terbaik mereka selama berada di sekolah. Dari isi nasehat tersebut, maka kami bisa menyimpulkan bahwa tujuan kunjungan kepala desa dan lurah adalah untuk memberikan nasihat dan motivasi kepada siswa. Kedua tokoh tersebut umendorong para siswa agar mereka dapat menjadi manusia yang berkarakter baik dan menjadi siswa yang 
Ardilla Elfira Safitri, Victor Novianto

berprestasi akademik maupun non akademik" (Wawancara kepada KS, 19 September 2018 jam 09.00-09.20 WIB).

Beberapa kesulitan dan kendala implementasi pendidikan karakter pada pembelajaran IPS oleh guru IPS MTs An-Nawawi 01 Berjan Purworejo tersebut, antara lain:

1) Sekolah mengalami keterbatasan media pembelajaran dan buku penunjang untuk mata pelajaran IPS kurikulum 2013 yang disediakan untuk siswa, sehingga timbul berbagai macam kesulitan untuk mengajak siswa belajar mandiri. Siswa cenderung mengalami kesulitan ketika guru mendorong siswa untuk belajar secara mandiri.

2) Tidak ditemukan kesulitan dan kendala dalam menanamkan karakter keimanan karena siswa telah dididik dan ditanamkan nilai-nilai karakter karakter tersebut untuk menjadi manusia yang beriman dan bertaqwa oleh pengurus Pondok Pesantren

3) Meskipun telah memberi teguran dan hukuman, namun siswa sering salah menjadwal mata pelajaran dan berakibat tidak membawa buku pelajaran yang ditentukan, sehingga mau tidak mau mereka harus kembali lagi ke asrama Pondok Pesantren untuk mengambil kembali buku pelajaran yang tertinggal. Siswa juga sering terlambat mengerjakan dan mengumpulkan tugas yang diberikan oleh guru karena padatnya kegiatan di asrama Pondok Pesantren yang menyebabkan siswa kurang memiliki waktu untuk mengerjakan tugas.

4) Kesulitan dalam mengajarkan dan melatih siswa untuk bisa mengembangkan kreativitas mereka khususnya dalam belajar IPS seperti kesulitan dalam mengajak dan mendorong siswa untuk menjawab pertanyaan yang diajukan oleh guru dengan menggunakan bahasa sendiri. Siswa juga mengalami kesulitan ketika guru mendorong siswa untuk menunjukkan kemampuan 
mereka dalam mengajukan pertanyaan, berpikir kritis, dan mengemukakan pendapat.

Kurangnya pemahaman dan pengetahuan guru IPS MTs AnNawawi 01 Berjan Purworejo tentang implementasi pendidikan karakter, menyebabkan proses implementasi pendidikan karakter pada pembelajaran IPS di MTs An-Nawawi 01 Berjan Purworejo menjadi terhambat. Oleh karena itu, sekolah berusaha untuk bekerja keras dengan melakukan berbagai upaya, dalam rangka untuk mengatasi kesulitan dan kendala yang terjadi dalam melaksanakan pendidikan karakter di lingkungan sekolah.

\section{Simpulan}

Berdasarkan hasil penelitian tersebut, maka dapat ditapat ditarik menjadi 3 simpulan. Simpulan yang dapat ditarik berdasarkan hasil penelitian tersebut adalah: Pertama, bentuk implementasi pendidikan karakter peduli sosial, kemandirian, keimanan, kedisiplinan, dan kreatif yang diterapkan pada pembelajaran IPS, antara lain siswa diberi kesempatan untuk bermain peran di kelas; siswa diberi tugas individu, tugas kelompok untuk presentasi di depan kelas, dan mengambil buku di perpustakaan secara mandiri; siswa diberi pengertian tentang tata cara mempelajari ilmu agama dengan baik dan benar; siswa harus menggunakan seragam sesuai dengan peraturan sekolah dan mengembalikan buku sesuai dengan jumlah dan tempatnya, dan siswa mengerjakan tugas dan menceritakan ulang materi dari LCD.

Kedua, siswa telah memiliki sikap peduli sosial, mandiri, beriman, disiplin, dan kreatif. Dalam pembelajaran IPS, siswa bersedia meminjamkan alat tulis kepada teman yang membutuhkan; mengerjakan tugas secara mandiri dan tidak bergantung kepada orang lain; membaca asmaul khusna dan 
Ardilla Elfira Safitri, Victor Novianto

berdo'a kegiatan pembelajaran IPS dimulai; tidak terlambat masuk ke sekolah dan mengumpulkan tugas tepat waktu; dan belajar menjawab pertanyaan guru dengan menggunakan bahasa sendiri.

Ketiga, MTs An-Nawawi 01 Berjan Purworejo menyelenggarakan pendidikan karakter karena seluruh siswa merupakan santri dan santriwati dari Pondok Pesantren dan sekolah ingin meneruskan tugas pondok dan peran Pondok Pesantren untuk mendidik dan membentuk siswa menjadi seorang ahli agama. Faktor penghambat implementasi pendidikan karakter di MTs An-Nawawi 01 Berjan Purworejo adalah beberapa guru MTs An-Nawawi 01 Berjan Purworejo kurang memahami tentang makna dan tata cara melaksanakan pendidikan karakter. Kurangnya pemahaman guru tersebut yang menyebabkan guru mengalami kesulitan dan kendala dalam pengimplementasikan pendidikan karakter tersebut kepada siswa.

\section{DAFTAR PUSTAKA}

Aeni, A. Nur. 2014. Pendidikan karakter Untuk Mahasiswa PGSD. Bandung: UPI Press

Amri, Sofan, dkk. 2011. Implementasi Pendidikan Karakter dalam Pembelajaran; Strategis Analisis dan Pengembangan Karakter Siswa dalam Proses Pembelajaran. Jakarta: Prestasi Pustaka

Berkowitz, W. M., \& Bier, C. M. 2005. "What Works In Caracter Education: A Research - Driven Guide for Educators". CEP, hlm. 2

Jalil, Jasman. 2018. Pendidikan Karakter: Implementasi Oleh Guru, Kurikulum, Pemerintah dan Sumber Daya Pendidikan. Sukabumi: CV Jejak

Jones, RIP. 2003. Intructing Social Teory. (Terj). Achmad Febriyadi Saifuddin. 2009. Pengantar Teori-Teori Sosial. Jakarta: Yayasan Pustaka Obor Indonesia. 
JIPSINDO No. 1, Volume 6, Maret 2019

Kementrian Pendidikan Nasional Republik Indonesia. 2010. Panduan Pelaksanaan Pendidikan Karakter. Jakarta: Puskurbuk

Lickona, Thomas. 1992. Educating For Character: How Our Schools Can Teach Respect and Responsibility. (Terj). Juma Abdu Wamaungo \& Jean Antunes Rudolf Zien. 2012. Mendidik Untuk Membentuk Karakter: Bagaimana Sekolah Dapat Memberikan Pendidikan Tentang Sikap Hormat dan Bertanggung Jawab. Jakarta: Bumi Aksara.

Miles, M. B and Huberman, A. Michael. 2007. Analisis Data Kualitatif. Buku Sumber Tentang Metode-Metode Baru. Jakarta: Universitas Indonesia Press.

Moleong, J. Lexy. 2014. Metodologi Penelitian Kualitatif. Bandung: PT. Remaja Rosdakarya.

Mumpuni, Atikah. 2018. Integrasi Nilai Karakter dalam Buku Pelajaran: Analisis Konten Buku Teks Kurikulum 2013. Sleman: Deepublish Publisher

Permendikbud RI Nomor 22 Tahun 2016 tentang Standar Proses untuk Satuan Pendidikan Dasar dan Menengah

Permendikbud RI Nomor 64 Tahun 2013 tentang Standar Isi Pendidikan Dasar dan Menengah

Permendiknas RI Nomor 41 Tahun 2007 tentang Standar Proses untuk Satuan Pendidikan Dasar dan Menengah

Raka, Gede, dkk. 2011. Pendidikan Karakter di Sekolah: Dari Gagasan ke Tindakan. Jakarta: Elex Media Komputindo

Sapriya. 2009. Pendidikan IPS: Konsep dan Pembelajaran. Bandung: PT. Remaja Rosdakarya

Sugiyono. 2012. Metode Penelitian Pendidikan Pendekatan Kuantitatif, Kualitatif, dan R\&D. Bandung: Alfabeta Bandung

Supardan, Dadang. 2015. Pembelajaran Ilmu Pengetahuan Sosial: Perspektif Filosofi dan Kurikulum. Jakarta: Bumi Aksara.

Supardi. 2011. Dasar-Dasar Ilmu Sosial. Yogyakarta: Ombak 
Ardilla Elfira Safitri, Victor Novianto

Trianto. 2010. Model Pembelajaran Terpadu: Konsep, Strategi, dan Implementasinya dalam Kurikulum Tingkat Satuan Pendidikan (KTSP). Jakarta: Bumi Aksara.

Undang-Undang No. 20 Tahun 2003 tentang Sistem Pendidikan Nasional

Wahyuni, Sri, dkk. 2012. Perencanaan Pembelajaran Bahasa Berkarakter. Bandung: PT. Refika Aditama

Wibowo, Agus. 2012. Pendidikan Karakter: Strategi Membangun Karakter Bangsa Berperadaban. Yogyakarta: Pustaka Pelajar.

Yaumi, Muhammad. 2014. Pendidikan Karakter: Landasan, Pilar, dan Implementasi. Jakarta: Prenadamedia Grup

Zubaedi. 2011. Desain Pendidikan Karakter: Konsepsi dan Aplikasinya dalam Lembaga Pendidikan. Jakarta: Kencana Prenada Media Grup

Zuchdi, Darmiyati. 2011. Pendidikan Karakter dalam Perspektif Teori dan Praktik. Yogyakarta: UNY Press 